\title{
The $\mathrm{pK}_{\mathrm{a}}$ values of ligands and stability constants of the complexes of $\mathrm{Fe}(\mathrm{III}), \mathrm{Cu}(\mathrm{II})$ and $\mathrm{Ni}$ (II) with some hydroxamic acids: a compara- tive study of three different potentiometric methods
}

\author{
R. Senthilnithy ${ }^{1}$, M.D.P. de Costa ${ }^{2 *}$ and H.D. Gunawardhana ${ }^{2}$ \\ ${ }^{1}$ Department of Physical Sciences, Faculty of Applied Science, South Eastern University of Sri Lanka, University Park, Oluvil. \\ 2 Department of Chemistry, Faculty of Science, University of Colombo, Colombo 03.
}

\begin{abstract}
The determination of ionization constants and the chelating properties exhibited by a series of derivatives of $\mathrm{N}$-phenylbenzohydroxamic acid, N-phenyllaurohydroxamic acid and 1-naphthalenemethylimminodiacetohydroxamic acid type ligands toward $\mathrm{Fe}(\mathrm{III}), \mathrm{Cu}(\mathrm{II})$ and $\mathrm{Ni}$ (II) ions were studied by $\mathrm{pH}$-metric method. The data obtained by $\mathrm{pH}$-metric method were analyzed by three standard methods namely, Bjerrum's method, Irving and Rossotti method, and Sarkar and Kruck method. The ionization constants of hydroxamic acids and the stability constants of metal-ligand complexes were calculated using the above three methods and it was found that the values obtained closely agreed with each other. The evaluation of the calculated stability constants shows that the substituent effect on the N-phenyl ring leads to more basic character at the carbonyl oxygen and it influences significantly the stability of the complex species formed by the hydroxamate moieties. The stability constant and the species distribution of $\mathrm{Fe}(\mathrm{III})$ - 1-naphthalenemethylimminodiacetohydroxamic acid system at physiological $\mathrm{pH}$ range $(6.8$ - 7.2) suggest that 1-naphthalenemethylimminodiacetohydroxamic acid is an effective source for the iron overload.
\end{abstract}

Keywords: Bjerrum method, hydroxamic acid, Irving and Rossotti method, Sarkar and Kruck method, stability constant

\section{INTRODUCTION}

Hydroxamic acids are a group of naturally occurring or synthetic weak organic acids having the general formula $\mathrm{RC}(=\mathrm{O}) \mathrm{N}\left(\mathrm{R}^{\prime}\right) \mathrm{OH}$. They are weaker proton donors than the structurally related carboxylic acids $\mathrm{RC}(=\mathrm{O}) \mathrm{OH}$. These acids are widespread in the tissues of plants, in metabolites of bacteria and fungi, including complex compounds. With regard to the significant complex-forming ability of hydroxamic acid, the biological activity of the ligands must be closely correlated with the formation of their metal complexes ${ }^{1,2}$. In this study, potentiometric data were analyzed by three standard analytical procedures namely, Bjerrum method ${ }^{3}$, Irving and Rossotti method ${ }^{4}$, and Sarkar and Kruck method ${ }^{5}$ and the values obtained for the ionization constants and the stability constants of the complexes of $\mathrm{Fe}(\mathrm{III}), \mathrm{Cu}(\mathrm{II})$ and $\mathrm{Ni}$ (II) formed with some hydroxamic acids were compared.

\section{METHODS AND MATERIALS}

Calculation of ionization constant: Bjerrum ${ }^{3}$ used Expression (1) to calculate the $\tilde{n}_{H}$ values (average number of hydrogen ions bound to the ligand) at different $\mathrm{pH}$ values and plotted a graph $\tilde{\mathrm{n}}_{\mathrm{H}} \mathrm{Vs} \mathrm{pH}$ and equated the value of $\mathrm{pK}_{\mathrm{a}}$ to the value of $\mathrm{pH}$ at which the value of $\tilde{n}_{H}=0.5$.

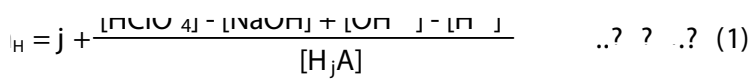

$\mathrm{j}$ is the total number of ionizable hydrogen in the ligand, $\left[\mathrm{H}_{\mathrm{j}} \mathrm{A}\right]$ is calculated amount of $\mathrm{H}_{\mathrm{j}} \mathrm{A}$ added, $[\mathrm{NaOH}]$ is calculated amount of $\mathrm{NaOH}$ added, $\left[\mathrm{HClO}_{4}\right]$ is calculated amount of $\mathrm{HClO}_{4}$ added, $\left[\mathrm{H}^{+}\right]=$antilog $(-\mathrm{pH})$ and $\left[\mathrm{OH}^{-}\right]=\mathrm{K}_{\mathrm{w}} /\left[\mathrm{H}^{+}\right]$.

H. M. Irving and H. S. Rossotti ${ }^{4}$ used Expression (2) to calculate the $\tilde{n}_{H}$ values at different $\mathrm{pH}$ values and used Expression(3)tocalculate theionization constantofaligand.

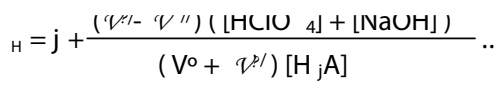

$\left.\operatorname{sg}\left(\frac{\left(1 I_{H}-j+1\right)}{\left(j-i+1-\tilde{n}_{H}\right)}\right) p H=p K \oiint_{1}\right)$ 
where $\mathrm{V}^{\circ}$ is the initial volume of the solution, $V^{\prime}$ and $V^{\prime \prime}$ are the volumes of the base used to bring the solutions (i) mineral acid alone and (ii) a mixture of same amount of mineral acid and the ligand to the same $\mathrm{pH}$ value.

Theo P.A. Kruck and Bibudhendra Sarkar ${ }^{5}$ performed a series of titrations of weak acid, each differing in $\mathrm{C}_{\mathrm{A}}$ where $\mathrm{C}_{\mathrm{A}}$ is the total concentration of ligand in all forms and used Expression (4) to calculate the values of $\tilde{n}_{H}$ at different $\mathrm{pH}$ values.

$$
\tilde{n}_{H}=j-\left(\frac{\partial C_{N a O H}}{\partial C_{A}}\right)_{H}
$$

Calculation of stability constants: Bjerrum $^{3}$ used Expression (5) and (6) to calculate the stability constants values.

$$
\begin{gathered}
\tilde{\mathrm{n}}_{\mathrm{A}}=\frac{\mathrm{T}_{\mathrm{A}}^{0} ?\left(\mathrm{~T}_{\mathrm{H}} ?[\mathrm{H}]\right) / \tilde{\mathrm{n}}_{\mathrm{H}}}{\mathrm{T}_{\mathrm{M}}{ }^{0}} \\
\ddot{?} \stackrel{\left(\mathrm{i}-\tilde{\mathrm{n}}_{\mathrm{A}}\right) \beta_{\mathrm{i}}[\mathrm{A}]^{\mathrm{i}}=}{\mathrm{i}=0}
\end{gathered}
$$

where; $A$ is the total concentration of ligand; A, ${ }^{\breve{M}}$ is the total concentration of metal; $M, T_{H}$ is the total concentration of proton (bound + unbound) present in the solution and $\tilde{n}_{A}$ is the average number of ligands bound per metal.

Irving and Rossotti ${ }^{4}$ used Expression (2), (7), (8) and (9) to calculate the stability constants values.

$$
\begin{aligned}
& A=-\log [A]=\log \left\{\frac{\stackrel{?}{i=0} \beta_{i}^{H}[H]^{i}}{T_{A}^{0} ? \tilde{n}_{A} T_{M}^{0}}\left(\frac{\left(V^{0}+V^{P} / / /\right)}{V^{0}}\right)\right\} \quad . . ? ? ? \ldots ? \text { (7) } \\
& \log K_{i}=p A-\log \left(\frac{\left(i-\tilde{n}_{A}\right)}{\left(\tilde{n}_{A}-i+1\right)}\right) \quad . ? ? ? . . ?(8) \\
& \tilde{n}_{A}=\frac{\left(\mathcal{V}^{\prime / I /}-\mathcal{V}^{\prime \prime}\right)\left(\left[\mathrm{HClO}{ }_{4}\right]+[\mathrm{NaOH}]\right)}{\left(V^{0}+\mathcal{V}^{\prime \prime /}\right) \tilde{n}_{H} T_{M}^{0}} ? . .(9)
\end{aligned}
$$

$$
\begin{aligned}
& \mathrm{pM}+\mathrm{rA}+\mathrm{qH} \rightleftharpoons \mathrm{MpHqA} \text { r }
\end{aligned}
$$

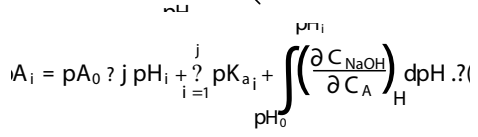

$$
\begin{aligned}
& \mathrm{M}_{\mathrm{i}}=\mathrm{pM}_{0}+\int_{\mathrm{pH}}^{\mathrm{pH}}\left(\frac{\partial \mathrm{C}_{\mathrm{NaOH}}}{\partial \mathrm{C}_{\mathrm{M}}}\right)_{\mathrm{H}} \mathrm{dpH} \text { ? } \\
& ?_{\mathrm{pqr}}=\frac{\left[\mathrm{MpHqA}_{\mathrm{r}}\right]}{[\mathrm{M}]^{\mathrm{p}}[\mathrm{H}]^{\mathrm{q}}[\mathrm{A}]^{\mathrm{r}}} \text { ?... } \\
& \left(C_{M} ?\left[M_{i}\right]\right)=? p \text { pqr }\left[M_{i}\right]^{p}\left[H_{i}\right]^{q}\left[A_{i}\right]^{r} ? ?
\end{aligned}
$$

where $\mathcal{V}^{\prime \prime \prime}$ is the volume of base used to bring the mixture of solution mineral acid, ligand and metal ion to a same $\mathrm{pH}$ value, $\mathrm{K}_{\mathrm{i}}$ is the stepwise stability constant and $\beta_{\mathrm{i}}$ is the overall stability constant.

Sarkar and Kruck $^{5}$ used Expression (10), (11), (12) and (13) to calculate the stability constants and species distribution of the complexes formed in the following equilibrium.

Experimental: Potentiometric titrations were performed using a Metrohm 702 SM Titrino Auto Titrater and all titrations were thermostated to $25^{\circ} \mathrm{C}$ using a water circulating pump. Metrohm 6.0203.100 combined $\mathrm{pH}$ glass electrode was used to collect the experimental data. GBC 932 plus atomic absorption spectrometer was used to measure the concentration of the metal ions in the stock solutions. Absorption spectra were obtained using Jasco V-500 and Helios thermo spectronic spectrophotometer. ${ }^{1} \mathrm{H}$ NMR spectra were obtained on a Bruker $200 \mathrm{MHz}$ and Varian Mercury-300 MHz instrument. Infrared spectra were recorded on a Thermo Nicolet AVATAR-320 FT/ IR spectrophotometer.

All chemicals were of analytical reagent grade from Aldrich or Merck of highest purity available and used without any further purification, except for vacuum drying. HPLC grade methanol solvent was used in all spectroscopic measurements. The solutions were prepared with double distilled water. All glassware were soaked overnight in a 5\% nitric acid solution and carefully cleaned with doubly distilled water and dried in a dust-free environment prior to use. The standard stock solutions of iron(III), copper(II) and nickel(II) were prepared from their corresponding sulphate salts. All measurements were carried out at a constant ionic strength using $0.2 \mathrm{~mol} \mathrm{dm} \mathrm{NaClO}_{4}$. Carbonate free $\mathrm{NaOH}$ solution of known concentration (about $0.25 \mathrm{~mol} \mathrm{dm}^{-3}$ ) was used as the titrant. The $\mathrm{pH}$-metric titrations were performed throughout the $\mathrm{pH}$ range of 2.0-12.5 or below the precipitation on samples of

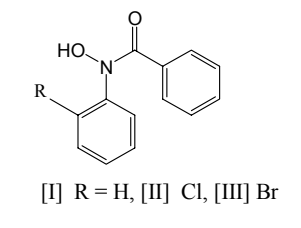

[IV] $\mathrm{R}=\mathrm{OMe}$ and $[\mathrm{V}] \mathrm{R}=\mathrm{Me}$
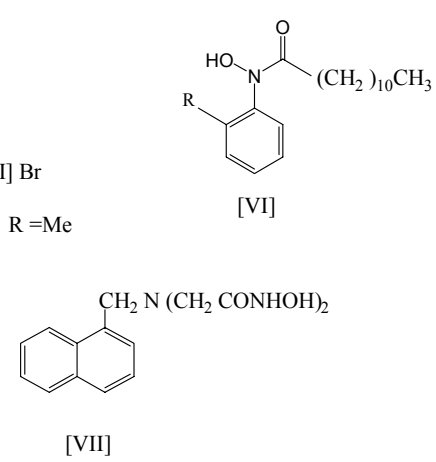

Figure 1: Structures of compounds synthesized in this study 
$100 \mathrm{~cm}^{3}$. The ligand concentrations were varied in the range of $1.0 \times 10^{-3} \mathrm{~mol} \mathrm{dm}^{-3}$ to $5.0 \times 10^{-3} \mathrm{~mol} \mathrm{dm}^{-3}$. In all cases, the metal to ligand ratio was maintained greater than 1:5 to avoid hydrolysis and possible polymerization. Since the ligands and also the metal complexes are insoluble in water as well as in water-methanol medium (above $\mathrm{pH}=7$ ), 1:1 water-ethanol solvent system was maintained throughout the experiment except for N-phenyllauroylhydroxamic acid for which 1:3 waterethanol solvent system was employed.

Synthesis of compounds [I]-[VI]: N-phenyllauroylhydroxamic acid [VI], N-phenylbenzohydroxamic acid [I] and its phenyl derivatives such as (o-chloro)phenyl[II], (o-bromo)phenyl-[III], (o-methoxy)phenyl-[IV] and (o-methyl)phenyl-[V], benzohydroxamic acids were synthesized by the general procedure as described in the literature ${ }^{6}$ (reduction of appropriate nitro compound and then coupled with benzoyl chloride for compounds [I]-[V] and with lauroyl chloride for compound [VI]).

Synthesis of compound [VII]: Solutions of 1-naphthalenemethylamine $\left(2.8 \mathrm{~cm}^{3}, 0.019 \mathrm{~mol}\right)$ in $50 \mathrm{~cm}^{3}$ dry acetonitrile and ethylbromoacetate $\left(4.40 \mathrm{~cm}^{3} ; 0.04 \mathrm{~mol}\right)$ in $25 \mathrm{~cm}^{3}$ dry acetonitrile were added simultaneously and dropwise over a period of $4 \mathrm{~h}$ to a warm magnetically stirred suspension of potassium carbonate $(25 \mathrm{~g})$ in $50 \mathrm{~cm}^{3}$ dry acetonitrile. The resulting mixture was refluxed for $16 \mathrm{~h}$ on a water bath, cooled to room temperature, concentrated, filtered, and the filtrate was evaporated to dryness under reduced pressure to give 1-naphthalenemethylimminodiethylacetate as an off white product (yield 80\%).

A solution of diethyl-1-napthalenemethyliminodiacetate $(3.0 \mathrm{~g}, 0.01 \mathrm{~mol})$ in absolute ethanol $\left(25 \mathrm{~cm}^{3}\right)$ was added dropwise while stirring into a solution of hydroxylamine $(0.02 \mathrm{~mol})$ in absolute ethanol $\left(30 \mathrm{~cm}^{3}\right)$ at $\mathrm{pH} 8$ cooled in an ice-water bath. The resulting solution was stirred for further sixteen hours at ice-water temperature, and filtered. The filtrate was concentrated and cooled in ice-water bath to obtain 1-napthalenemethyliminodiacetohydroxamic acid [VII], as a white product (yield $88 \%$ ).

\section{RESULTS AND DISCUSSION}

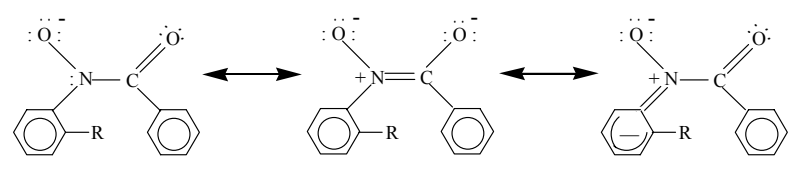

Figure 2: Resonance structures of phenyl derivatives of $\mathrm{N}$-phenylbenzohydroxamic acid anion
The electron accepting nature of the phenyl group, the substituents of phenyl ring derivatives on the $\mathrm{N}$ atom $\left(\mathrm{R}_{\mathrm{N}}\right.$ substituents) reflect a greater effect due to both resonance and inductive effects ${ }^{7}$. Therefore, it can be expected that the superposition of the substituent effects can modify the ionization constant of the chelate and the stability constant of the metal chelates. In this study, the ionization constants for compounds [I]-[VII] (Table 1) fall in the normal range $\left(\mathrm{pK}_{\mathrm{a}}=8-10\right)$ for all hydroxamic

Table 1: The comparison of $\mathrm{pK}_{\mathrm{a}}$ values obtained for compounds [I]-[VII]

\begin{tabular}{|c|c|c|c|}
\hline Compound & $\begin{array}{l}\text { Bjerrum } \\
\text { method }\end{array}$ & $\begin{array}{l}\text { Irving and Rossotti } \\
\text { method }\end{array}$ & $\begin{array}{c}\text { Sarkar and Kruck } \\
\text { method }\end{array}$ \\
\hline$[\mathrm{I}]$ & 9.80 & 9.80 & 9.81 \\
\hline [II] & 9.64 & 9.64 & 9.64 \\
\hline [III] & 9.73 & 9.72 & 9.72 \\
\hline [IV] & 9.97 & 9.96 & 9.97 \\
\hline [V] & 9.90 & 9.92 & 9.90 \\
\hline [VI] & 11.21 & 11.16 & 11.21 \\
\hline [VII] $\mathrm{pK}_{\mathrm{a}}$ & 9.60 & 9.64 & 9.62 \\
\hline $\mathrm{pK}_{\mathrm{a}}$ & 10.74 & 10.54 & 10.57 \\
\hline
\end{tabular}

acids. It has been found that the $\mathrm{pK}_{\mathrm{a}}$ values obtained by the three methods are in good agreement with each other after the least square refinement. In least square refinement a fixed value $10^{-8}$ was used as error fit in all cases.

The relative order of $\mathrm{pK}_{\mathrm{a}}$ values obtained for the phenyl derivatives of N-phenylbenzohydroxamic acid by Sarkar and Kruck method for the systems studied is as follows:

N-(o-methoxy)phenylbenzohydroxamic > N- (o-methyl) phenylbenzohydroxamicacid $>\mathrm{N}$-phenylbenzohydroxamic acid $>\mathrm{N}$-(o-bromo)phenylbenzohydroxamic acid $>\mathrm{N}$-(ochloro)phenylbenzohydroxamic acid.

Due to the inductive effect of the long chain attached to the carbonyl group $\left(\mathrm{R}_{\mathrm{C}}\right.$ substituent $)$ and the solvent system used the $\mathrm{pK}_{\mathrm{a}}$ value obtained for $\mathrm{N}$-phenyllauroylhydroxamic acid [VI] is greater than that of N-phenylbenzohydroxamic acid.

There is an expectation that $\mathrm{pK}_{\mathrm{a}_{1}}<\mathrm{pK}_{\mathrm{a}_{2}}$ and that for statistical reasons $\mathrm{pK}_{\mathrm{a}_{1}}-\mathrm{pK}_{\mathrm{a}_{2}} \sim 0.6$ for a diprotic acid with two equivalent acid sites ${ }^{8}$. Table 1 shows that in compound [VII], $\mathrm{pK}_{\mathrm{a}_{1}}<\mathrm{pK}_{\mathrm{a}_{2}}$ slightly greater than that expected (0.6), suggesting some degree of intramolecular interaction between the two hydroxamic acid units. The 
enhanced difference in $\mathrm{pK}_{\mathrm{a}_{1}}$ and $<\mathrm{pK}_{\mathrm{a}_{2}}$ is due to a lower value for $\mathrm{pK}_{\mathrm{a}}$.

This is in agreement with deduction of Crumbliss et al. ${ }^{8}$ where the stability of the conjugate base $\mathrm{HA}^{-}$occurs

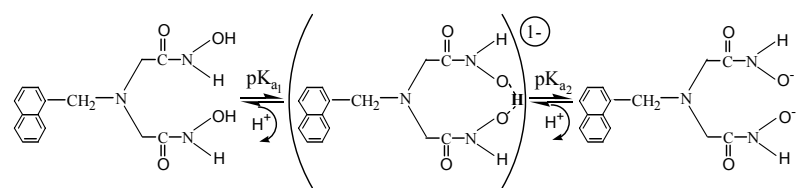

due to the interaction through $\mathrm{H}$ bonding between the hydroxamic acid functional groups associated with long

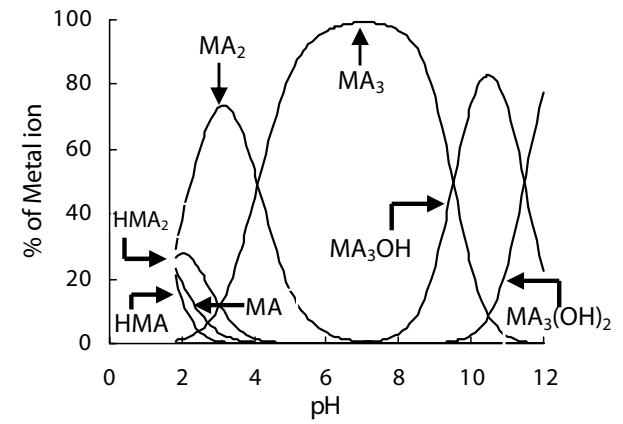

(a)

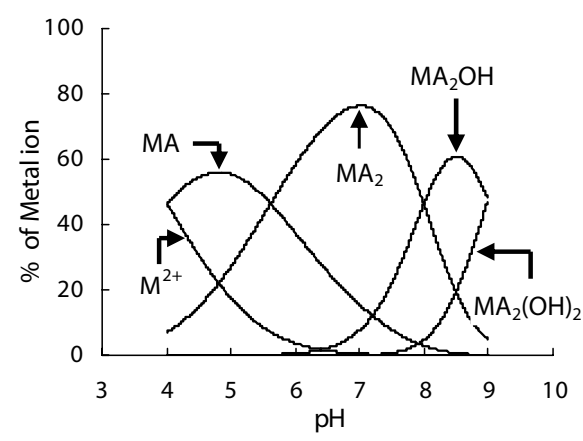

(c)

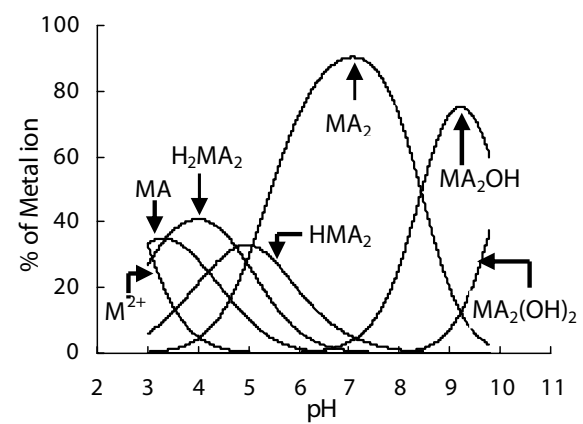

(e) chain or a big choromophore. The ab-inito calculations ${ }^{9}$ carried out by our research group also confirm this. This intramolecular H-bonding formed in between the two hydroxamic acid groups is illustrated above:

In general, the stability constants calculated (Table 2-8) for all metal-ligand complexes of compounds [I]-[VII] by Bjerrum method, Irving and Rossotti method and Sarkar and Kruck method are in reasonably good agreement with each other after the least square refinement. For all metal ions [Fe(III), $\mathrm{Cu}$ (II) and $\mathrm{Ni}(\mathrm{II})]$ studied the distribution of species of the compounds [I]$[\mathrm{VI}]$ in the physiological $\mathrm{pH}$ range $(6.7-7.2)$ is almost

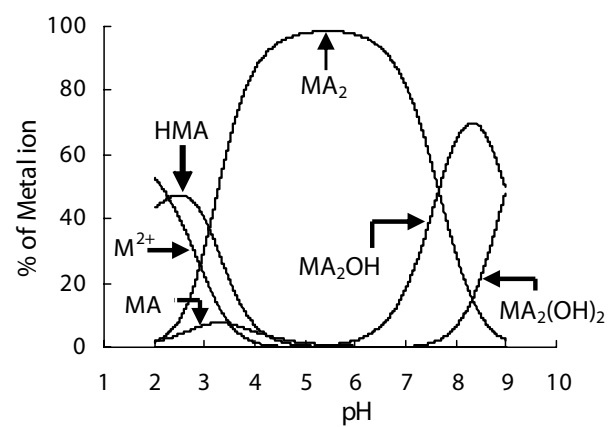

(b)

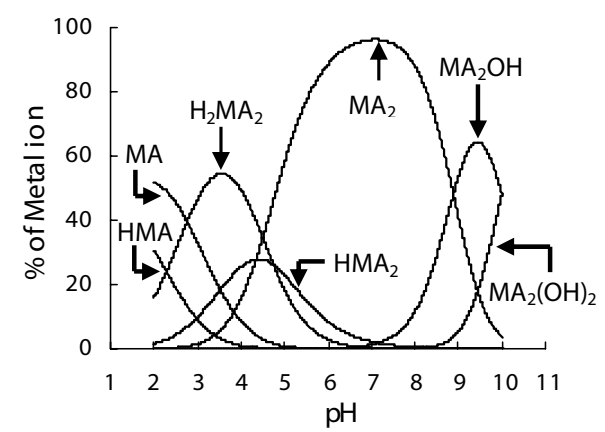

(d)

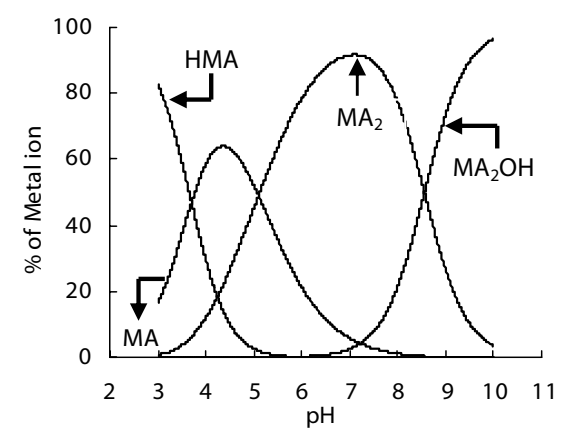

(f)

Figure 3: Species distribution of (a) Fe(III)-compound (I), (b) $\mathrm{Cu}$ (II)-compound (I), (c) Ni(II)-compound (I), (d) Fe(III)compound (VII), (e) $\mathrm{Cu}(\mathrm{II})$-compound (VII), and (f) Ni(II)-compound (VII) using Sarkar and Kruck method as representative sets 
identical, but in acidic and basic region the relative amount of species formed and the $\mathrm{pH}$ values of maxima are slightly different. The species distribution curves of
$\mathrm{Fe}(\mathrm{III}), \mathrm{Cu}(\mathrm{II})$ and $\mathrm{Ni}(\mathrm{II})$ of N-phenylbenzohydroxamic acid are shown in Figure 3 (a)-(c) as a representative set and that of 1-naphthalenemethylimminodiacetohydroxamic

Table 2: The stability constant values ( $\log \beta$ ) for $\mathrm{Fe}(\mathrm{III}), \mathrm{Cu}(\mathrm{II})$ and $\mathrm{Ni}(\mathrm{II})$ complexes of $\mathrm{N}$-phenylbenzohydroxamic acid (I) system

\begin{tabular}{|c|c|c|c|c|c|c|c|}
\hline \multirow{2}{*}{$\begin{array}{l}\text { Metal } \\
\text { ion }\end{array}$} & \multicolumn{3}{|c|}{ Species } & \multirow{2}{*}{$\begin{array}{l}\text { Bjerrum } \\
\text { method }\end{array}$} & \multirow{2}{*}{$\begin{array}{l}\text { Irving and Rossotti } \\
\text { method }\end{array}$} & \multirow{2}{*}{$\begin{array}{l}\text { Sarkar and Kruck } \\
\text { method }\end{array}$} & \multirow[t]{2}{*}{ pH Range } \\
\hline & $\mathrm{M}_{\mathrm{p}}$ & $\mathrm{L}_{\mathrm{q}}$ & $\mathrm{H}_{\mathrm{r}}$ & & & & \\
\hline \multirow[t]{7}{*}{$\mathrm{Fe}(\mathrm{III})$} & 1 & 3 & -2 & & & 36.24 & $>10$ \\
\hline & 1 & 3 & -1 & & & 33.70 & $>7.8$ \\
\hline & 1 & 3 & 0 & 29.22 & 29.51 & 29.20 & $2-12$ \\
\hline & 1 & 2 & 1 & & & 21.87 & $2-4.5$ \\
\hline & 1 & 2 & 0 & 19.35 & 19.63 & 20.17 & $2-6.8$ \\
\hline & 1 & 1 & 1 & & & 11.25 & $<3.5$ \\
\hline & 1 & 1 & 0 & 9.58 & 9.72 & 9.55 & $<4$ \\
\hline \multirow[t]{6}{*}{$\mathrm{Cu}(\mathrm{II})$} & 1 & 2 & -2 & & & 25.54 & $>7.5$ \\
\hline & 1 & 2 & -1 & & & 21.28 & $>6$ \\
\hline & 1 & 0 & 3 & 15.72 & 15.60 & - & - \\
\hline & 1 & 0 & 2 & 12.65 & 12.62 & 12.89 & $2-9$ \\
\hline & 1 & 1 & 1 & & & 10.14 & $2-5$ \\
\hline & 1 & 1 & 0 & 7.20 & 7.29 & 7.17 & $2-5.5$ \\
\hline \multirow[t]{5}{*}{$\mathrm{Ni}(\mathrm{II})$} & 1 & 2 & -2 & & & 14.34 & $>7.5$ \\
\hline & 1 & 2 & -1 & & & 11.44 & $>6$ \\
\hline & 1 & 3 & 0 & 12.72 & 12.78 & & - \\
\hline & 1 & 2 & 0 & 8.01 & 7.80 & 7.96 & $4-9$ \\
\hline & 1 & 1 & 0 & 4.25 & 4.33 & 4.11 & $4-8.5$ \\
\hline
\end{tabular}

Table 3: The stability constant values ( $\log \beta)$ for $\mathrm{Fe}(\mathrm{III}), \mathrm{Cu}(\mathrm{II})$ and $\mathrm{Ni}(\mathrm{II})$ complexes of $\mathrm{N}$-(o-chloro)phenylbenzohydroxamic acid (II) system

\begin{tabular}{|c|c|c|c|c|c|c|c|}
\hline \multirow{2}{*}{$\begin{array}{l}\text { Metal } \\
\text { ion }\end{array}$} & \multicolumn{3}{|c|}{ Species } & \multirow{2}{*}{$\begin{array}{r}\text { Bjerrum } \\
\text { method }\end{array}$} & \multirow{2}{*}{$\begin{array}{l}\text { Irving and Rossotti } \\
\text { method }\end{array}$} & \multirow{2}{*}{$\begin{array}{c}\text { Sarkar and Kruck } \\
\text { method }\end{array}$} & \multirow[t]{2}{*}{ pH Range } \\
\hline & $\mathrm{M}_{\mathrm{p}}$ & $\mathrm{L}_{\mathrm{q}}$ & $\mathrm{H}_{\mathrm{r}}$ & & & & \\
\hline \multirow[t]{5}{*}{$\mathrm{Fe}(\mathrm{III})$} & 1 & 3 & -2 & & & 34.25 & $>10$ \\
\hline & 1 & 3 & -1 & & & 31.88 & $>7.7$ \\
\hline & 1 & 3 & 0 & 28.21 & 28.51 & 27.36 & $2-12$ \\
\hline & 1 & 2 & 0 & 18.78 & 18.87 & 18.49 & $2-6$ \\
\hline & 1 & 1 & 0 & 9.35 & 9.15 & 8.63 & $<4$ \\
\hline \multirow[t]{6}{*}{$\mathrm{Cu}(\mathrm{II})$} & 1 & 2 & -2 & & & 25.31 & $>7.5$ \\
\hline & 1 & 1 & -2 & & & 21.06 & $>5.8$ \\
\hline & 1 & 3 & 0 & 15.07 & 1514 & - & - \\
\hline & 1 & 2 & 0 & 12.48 & 12.16 & 12.21 & $2-9$ \\
\hline & 1 & 1 & 1 & & & 9.74 & $<5$ \\
\hline & 1 & 1 & 0 & 6.88 & 6.73 & 6.84 & $2-5$ \\
\hline \multirow[t]{5}{*}{$\mathrm{Ni}(\mathrm{II})$} & 1 & 2 & -2 & & & 12.73 & $>7.3$ \\
\hline & 1 & 2 & -1 & & & 10.32 & $>6$ \\
\hline & 1 & 3 & 0 & 12.17 & 12.18 & - & - \\
\hline & 1 & 2 & 0 & 7.48 & 7.53 & 7.28 & $4-9$ \\
\hline & 1 & 1 & 0 & 3.83 & 3.83 & 3.83 & $4-8.5$ \\
\hline
\end{tabular}


Table 4: The stability constant values $(\log \beta)$ for $\mathrm{Fe}(\mathrm{III}), \mathrm{Cu}(\mathrm{II})$ and $\mathrm{Ni}(\mathrm{II})$ complexes of N-(o-bromo)phenyl benzohydroxamic acid (III) system

\begin{tabular}{|c|c|c|c|c|c|c|c|}
\hline \multirow{2}{*}{$\begin{array}{l}\text { Metal } \\
\text { ion }\end{array}$} & \multicolumn{3}{|c|}{ Species } & \multirow{2}{*}{$\begin{array}{l}\text { Bjerrum } \\
\text { method }\end{array}$} & \multirow{2}{*}{$\begin{array}{l}\text { Irving and Rossotti } \\
\text { method }\end{array}$} & \multirow{2}{*}{$\begin{array}{c}\text { Sarkar and Kruck } \\
\text { method }\end{array}$} & \multirow[t]{2}{*}{ pH Range } \\
\hline & $\mathrm{M}_{\mathrm{p}}$ & $\mathrm{L}_{\mathrm{q}}$ & $\mathrm{H}_{\mathrm{r}}$ & & & & \\
\hline \multirow[t]{6}{*}{$\mathrm{Fe}(\mathrm{III})$} & 1 & 3 & -2 & & & 35.58 & $>10$ \\
\hline & 1 & 3 & -1 & & & 33.23 & $>8$ \\
\hline & 1 & 3 & 0 & 28.71 & 28.99 & 28.80 & $2-12$ \\
\hline & 1 & 2 & 1 & & & 21.23 & $<4.5$ \\
\hline & 1 & 2 & 0 & 19.06 & 19.19 & 19.53 & $2-6.5$ \\
\hline & 1 & 1 & 0 & 9.46 & 9.47 & 8.81 & $<4$ \\
\hline \multirow[t]{6}{*}{$\mathrm{Cu}(\mathrm{II})$} & 1 & 2 & -2 & & & 25.42 & $>7$ \\
\hline & 1 & 2 & -1 & & & 21.17 & $>5.5$ \\
\hline & 1 & 3 & 0 & 15.19 & 15.18 & - & - \\
\hline & 1 & 2 & 0 & 12.41 & 12.41 & 12.48 & $2-9$ \\
\hline & 1 & 1 & 1 & & & 9.83 & $2-5$ \\
\hline & 1 & 1 & 0 & 6.95 & 6.90 & 6.91 & $2-6$ \\
\hline \multirow[t]{5}{*}{$\mathrm{Ni}(\mathrm{II})$} & 1 & 2 & -2 & & & 13.03 & $>7.5$ \\
\hline & 1 & 2 & -1 & & & 10.51 & $>6.2$ \\
\hline & 1 & 3 & 0 & 12.35 & 12.46 & - & - \\
\hline & 1 & 2 & 0 & 7.71 & 7.66 & 7.51 & $4-9$ \\
\hline & 1 & 1 & 0 & 4.00 & 4.09 & 4.03 & $4-8$ \\
\hline
\end{tabular}

Table 5: The stability constant values ( $\log \beta$ ) for $\mathrm{Fe}(\mathrm{III}), \mathrm{Cu}(\mathrm{II})$ and $\mathrm{Ni}(\mathrm{II})$ complexes of $\mathrm{N}$-(o-methoxy)phenyl benzohydroxamic acid (IV) system

\begin{tabular}{|c|c|c|c|c|c|c|c|}
\hline \multirow{2}{*}{$\begin{array}{l}\text { Metal } \\
\text { ion }\end{array}$} & \multicolumn{3}{|c|}{ Species } & \multirow{2}{*}{$\begin{array}{c}\text { Bjerrum } \\
\text { method }\end{array}$} & \multirow{2}{*}{$\begin{array}{l}\text { Irving and Rossotti } \\
\text { method }\end{array}$} & \multirow{2}{*}{$\begin{array}{c}\text { Sarkar and Kruck } \\
\text { method }\end{array}$} & \multirow[t]{2}{*}{ pH Range } \\
\hline & $\mathrm{M}_{\mathrm{p}}$ & $\mathrm{L}_{\mathrm{q}}$ & $\mathrm{H}_{\mathrm{r}}$ & & & & \\
\hline \multirow[t]{6}{*}{$\mathrm{Fe}(\mathrm{III})$} & 1 & 3 & -2 & & & 36.90 & $>10$ \\
\hline & 1 & 3 & -1 & & & 34.37 & $>7.8$ \\
\hline & 1 & 3 & 0 & 30.41 & 30.42 & 29.87 & $2-12$ \\
\hline & 1 & 2 & 0 & 20.12 & 20.24 & 21.30 & $2-7.5$ \\
\hline & 1 & 1 & 1 & & & 12.28 & $<3$ \\
\hline & 1 & 1 & 0 & 10.41 & 10.16 & 10.58 & $<4.5$ \\
\hline \multirow[t]{6}{*}{$\mathrm{Cu}(\mathrm{II})$} & 1 & 2 & -2 & & & 26.52 & $>7$ \\
\hline & 1 & 2 & -1 & & & 22.26 & $>5.5$ \\
\hline & 1 & 3 & 0 & 15.94 & 15.93 & - & - \\
\hline & 1 & 2 & 0 & 13.21 & 13.25 & 13.02 & $2-9$ \\
\hline & 1 & 1 & 1 & & & 10.78 & $2-5$ \\
\hline & 1 & 1 & 0 & 7.60 & 7.56 & 7.59 & $2-6.5$ \\
\hline \multirow[t]{6}{*}{$\mathrm{Ni}(\mathrm{II})$} & 1 & 2 & -2 & & & 15.04 & $>7.5$ \\
\hline & 1 & 2 & -1 & & & 12.04 & $>6.5$ \\
\hline & 1 & 3 & 0 & 15.62 & 15.75 & - & - \\
\hline & 1 & 2 & 0 & 8.91 & 8.95 & 8.51 & $4-9$ \\
\hline & 1 & 1 & 1 & & & 7.10 & $<6$ \\
\hline & 1 & 1 & 0 & 4.60 & 4.59 & 4.70 & $4-8.5$ \\
\hline
\end{tabular}


Table 6: The stability constant values ( $\log \beta$ ) for $\mathrm{Fe}(\mathrm{III}), \mathrm{Cu}(\mathrm{II})$ and $\mathrm{Ni}(\mathrm{II})$ complexes of N-(o-methyl)phenylbenzo hydroxamic acid (V) system

\begin{tabular}{|c|c|c|c|c|c|c|c|}
\hline \multirow{2}{*}{$\begin{array}{l}\text { Metal } \\
\text { ion }\end{array}$} & \multicolumn{3}{|c|}{ Species } & \multirow{2}{*}{$\begin{array}{l}\text { Bjerrum } \\
\text { method }\end{array}$} & \multirow{2}{*}{$\begin{array}{l}\text { Irving and Rossotti } \\
\text { method }\end{array}$} & \multirow{2}{*}{$\begin{array}{l}\text { Sarkar and Kruck } \\
\text { method }\end{array}$} & \multirow[t]{2}{*}{ pH Range } \\
\hline & $M_{p}$ & $\mathrm{~L}_{\mathrm{q}}$ & $\mathrm{H}_{\mathrm{r}}$ & & & & \\
\hline \multirow[t]{6}{*}{$\mathrm{Fe}(\mathrm{III})$} & 1 & 3 & -1 & & & 34.19 & $>7.8$ \\
\hline & 1 & 3 & 0 & 29.86 & 30.00 & 29.66 & $2-12$ \\
\hline & 1 & 2 & 1 & & & 22.19 & $2-4.5$ \\
\hline & 1 & 2 & 0 & 19.75 & 19.91 & 20.49 & $2-7$ \\
\hline & 1 & 1 & 1 & & & 11.47 & $<3$ \\
\hline & 1 & 1 & 0 & 9.96 & 10.00 & 9.77 & $<4$ \\
\hline \multirow[t]{6}{*}{$\mathrm{Cu}(\mathrm{II})$} & 1 & 2 & -2 & & & 25.87 & $>7$ \\
\hline & 1 & 2 & -1 & & & 21.61 & $>5.5$ \\
\hline & 1 & 3 & 0 & 15.88 & 15.76 & - & - \\
\hline & 1 & 2 & 0 & 13.01 & 13.07 & 12.97 & $2-9$ \\
\hline & 1 & 1 & 1 & & & 10.43 & $2-5$ \\
\hline & 1 & 1 & 0 & 7.32 & 7.31 & 7.38 & $2-6$ \\
\hline \multirow[t]{6}{*}{$\mathrm{Ni}(\mathrm{II})$} & 1 & 2 & -2 & & & 14.45 & $>7.5$ \\
\hline & 1 & 2 & -1 & & & 11.65 & $>6$ \\
\hline & 1 & 3 & 0 & 14.27 & 14.17 & - & - \\
\hline & 1 & 2 & 0 & 8.80 & 8.64 & 8.30 & $4-9$ \\
\hline & 1 & 1 & 1 & & & 6.62 & $<6.4$ \\
\hline & 1 & 1 & 0 & 4.47 & 4.49 & 4.38 & $4-8$ \\
\hline
\end{tabular}

Table 7: The stability constant values ( $\log \beta$ ) for $\mathrm{Fe}(\mathrm{III}), \mathrm{Cu}(\mathrm{II})$ and $\mathrm{Ni}(\mathrm{II})$ complexes of $\mathrm{N}$-phenyllauroylhydroxamic acid (VI) system.

\begin{tabular}{|c|c|c|c|c|c|c|c|}
\hline \multirow{2}{*}{$\begin{array}{l}\text { Metal } \\
\text { ion }\end{array}$} & \multicolumn{3}{|c|}{ Species } & \multirow{2}{*}{$\begin{array}{l}\text { Bjerrum } \\
\text { method }\end{array}$} & \multirow{2}{*}{$\begin{array}{l}\text { Irving and Rossotti } \\
\text { method }\end{array}$} & \multirow{2}{*}{$\begin{array}{l}\text { Sarkar and Kruck } \\
\text { method }\end{array}$} & \multirow[t]{2}{*}{$\mathrm{pH}$ Range } \\
\hline & $\mathrm{M}_{\mathrm{p}}$ & $\mathrm{L}_{\mathrm{q}}$ & $\mathrm{H}_{\mathrm{r}}$ & & & & \\
\hline \multirow[t]{5}{*}{$\mathrm{Fe}(\mathrm{III})$} & 1 & 3 & -1 & & & 34.03 & $>11$ \\
\hline & 1 & 3 & 0 & 33.47 & 33.75 & 32.88 & $3-12$ \\
\hline & 1 & 2 & 0 & 23.17 & 23.50 & 23.43 & $2-8$ \\
\hline & 1 & 1 & 1 & & & 13.36 & $<3$ \\
\hline & 1 & 1 & 0 & 11.99 & 11.93 & 11.92 & $2-5.5$ \\
\hline \multirow[t]{6}{*}{$\mathrm{Cu}(\mathrm{II})$} & 1 & 2 & -2 & & & 26.44 & $>7.2$ \\
\hline & 1 & 2 & -1 & & & 22.33 & $>5.6$ \\
\hline & 1 & 3 & 0 & 16.06 & 16.19 & - & - \\
\hline & 1 & 2 & 0 & 13.39 & 13.55 & 13.32 & $2-9$ \\
\hline & 1 & 1 & 1 & & & 10.69 & $<5$ \\
\hline & 1 & 1 & 0 & 8.01 & 8.02 & 7.99 & $2-6.5$ \\
\hline \multirow[t]{6}{*}{ Ni(II) } & 1 & 2 & -2 & & & 17.35 & $>7.2$ \\
\hline & 1 & 2 & -1 & & & 13.23 & $>6.7$ \\
\hline & 1 & 3 & 0 & 17.22 & 17.23 & - & - \\
\hline & 1 & 2 & 0 & 9.77 & 9.82 & 9.76 & $4-9$ \\
\hline & 1 & 1 & 1 & & & 7.56 & $<6$ \\
\hline & 1 & 1 & 0 & 4.94 & 4.88 & 4.99 & $4-8$ \\
\hline
\end{tabular}


Table 8: The stability constant values ( $\log \beta$ ) for $\mathrm{Fe}(\mathrm{III}), \mathrm{Cu}(\mathrm{II})$ and $\mathrm{Ni}(\mathrm{II})$ complexes of 1-napthalenemethyliminodiaceto hydroxamic acid (VII) system.

\begin{tabular}{|c|c|c|c|c|c|c|c|}
\hline \multirow{2}{*}{$\begin{array}{l}\text { Metal } \\
\text { ion }\end{array}$} & \multicolumn{3}{|c|}{ Species } & \multirow{2}{*}{$\begin{array}{l}\text { Bjerrum } \\
\text { method }\end{array}$} & \multirow{2}{*}{$\begin{array}{l}\text { Irving and Rossotti } \\
\text { method }\end{array}$} & \multirow{2}{*}{$\begin{array}{c}\text { Sarkar and Kruck } \\
\text { method }\end{array}$} & \multirow[t]{2}{*}{ pH Range } \\
\hline & $M_{p}$ & $\mathrm{~L}_{\mathrm{q}}$ & $\mathrm{H}_{\mathrm{r}}$ & & & & \\
\hline \multirow[t]{8}{*}{$\mathrm{Fe}(\mathrm{III})$} & 1 & 2 & -2 & & & 34.58 & $>8.5$ \\
\hline & 1 & 2 & 2 & & & 32.25 & $2-6.8$ \\
\hline & 1 & 2 & -1 & & & 30.58 & $>7$ \\
\hline & 1 & 3 & 0 & 30.96 & 30.99 & - & \\
\hline & 1 & 2 & 1 & & & 29.96 & $2-8$ \\
\hline & 1 & 2 & 0 & 25.51 & 25.44 & 25.46 & $3-10$ \\
\hline & 1 & 1 & 1 & & & 20.09 & $<4$ \\
\hline & 1 & 1 & 0 & 16.59 & 16.77 & 16.56 & $<5$ \\
\hline \multirow[t]{7}{*}{$\mathrm{Cu}(\mathrm{II})$} & 1 & 2 & -2 & & & 25.24 & $>8.5$ \\
\hline & 1 & 2 & 2 & & & 23.72 & $3-7$ \\
\hline & 1 & 2 & -1 & & & 21.24 & $>6.7$ \\
\hline & 1 & 3 & 0 & 25.16 & 25.04 & - & - \\
\hline & 1 & 2 & 1 & & & 20.63 & $3-8$ \\
\hline & 1 & 2 & 0 & 15.51 & 15.46 & 15.67 & $3-10$ \\
\hline & 1 & 1 & 0 & 12.79 & 12.82 & 12.84 & $<6$ \\
\hline \multirow[t]{5}{*}{$\mathrm{Ni}(\mathrm{II})$} & 1 & 2 & -1 & & & 15.53 & $>6.8$ \\
\hline & 1 & 3 & 0 & 15.29 & 15.49 & - & - \\
\hline & 1 & 2 & 0 & 10.31 & 10.24 & 10.09 & $3-10$ \\
\hline & 1 & 1 & 1 & & & 8.98 & $3-5.5$ \\
\hline & 1 & 1 & 0 & 7.44 & 7.35 & 7.28 & $3-8$ \\
\hline
\end{tabular}

acid is shown in Figure 3 (d)-(f). The results obtained for Fe(III) complexes of the compounds [I]-[VI] indicate that the $\mathrm{MA}_{3}$ complex is the major complex species formed in the physiological $\mathrm{pH}$ range. The relative order of the stability constants obtained is the same as that the order of $\mathrm{pK}_{\mathrm{a}}$ values of the hydroxamic acids obtained in this study.

\section{References}

1. Kehl H. (1982). Chemistry and Biology of Hydroxamic Acids. Karger, New York.

2. Fazary A.E., Khalil M.M., Fahmy A. \& Tantawy T.A. (2001). The role of hydroxamic acids in biochemical processes. Medical Journal of Islamic Academy of Sciences 14(3): 107-114.

3. Bjerrum J. (1950). On the tendency of the metal ions toward complex formation. Chemistry Reviews 46:(2) 381-399.

4. (a) Irving H.M. \& Rossotti H.S. (1954). The calculation of formation curves of metal complexes from $\mathrm{pH}$ titration curvesinmixedsolvents.Journalofthe ChemicalSociety: 2904-2910.

(b) Irving H.M. \& Rossotti H.S. (1953). Methods for computing successive stability constants from experimental formation curves. Journal of the Chemical Society: 3397-3408.
5. (a) Kruck T.P.A. \& Sarkar B. (1973). Equilibria of the simultaneously existing multiple species in the copper(II)-L-histidine system. Canadian Journal of Chemistry 51(21): 3549-3554.

(b) Mc Bryde W.A.E. (1973). On an extension of the use of $\mathrm{pH}$-titrations for determination of free metal and free ligand concentrations during metal complex formation.

Canadian Journal of Chemistry 51(21): 3572-3576.

6. Furniss B.S., Smith P.W.G., Hannaford A.J. \& Tatchell A.R. (1989). Vogel's Text Book of Practical Organic Chemistry, fifth edition, Pearson Education Limited, Longman group, U.K.

7. Brown D.A., Herlihy K.M. \& O'Shea S.K. (1999). Kinetics of iron (III) chelation from polynuclear oxohydroxy aggregates by hydroxamic acids: understanding ferritin iron(III) sequestration. Inorganic Chemistry 38: (23) 5198-5202.

8. Nguyen-van-Duong M.K., Guillot V., Nicolas L., Gaudemer A., Lowry L., Spasojević I. \& Crumbliss A. L. (2001). Synthesis, ligand $\mathrm{pKa}$, and $\mathrm{Fe}(\mathrm{III})$ complexation constants for a series of bipodal dihydroxamic acids. Inorganic Chemistry 40(23): 5948-5953.

9. Senthilnithy R., Gunawardhana H.D., Costa M.D.P. De \& Dissanayake D.P. (2006). Absolute $\mathrm{pK}_{\mathrm{a}}$ determination for N-phenylbenzohydroxamic acid derivatives. 